\title{
MODERN PRACTICE AND METHODS FOR INTEGRATION THROUGH GOLF
}

\author{
Ivaylo Zdravkov \\ National Sports Academy "Vassil Levski”, Sofia, Bulgaria
}

\begin{abstract}
The purpose of this pilot study is to clarify the mechanisms and the interested individuals and legal entities from the successful implementation of programs for socialization, social adaptation and integration through golf for persons at risk of social exclusion, to identify golf-based prevention practices which contribute to community building and the dissemination of messages of respect, citizenship, the fight against discrimination and exclusion. To clarify the ways how the golf can be used as a vehicle to promote social inclusion of people with disabilities and other vulnerable or disadvantaged groups. To analyze how to use golf can be used as tool in combating violence through community or national based projects and promoting reconciliation, peace, tolerance, and co-existence. This pilot study also identify how the golf can support new integration strategies and reinforce social cohesion as well as to prevent violence linked to exclusion and discrimination given that it encourages values including tolerance, respect, solidarity and fair-play and to identify sport-based prevention practices which contribute to community building and the dissemination of messages of respect, citizenship, the fight against discrimination and racism. The study shows that integration through golf, would increase the social and economic activity of the population and in a huge number of cases would have a positive effect on entire regions of the country investments, increased employment levels, development of a tourist destination, increased corporate social responsibility and donation, but also the lack of a qualified staff employed capable to deal with mental, physical or sensor disabilities in golf clubs.

Methodology: Structural content analysis, good practice analysis, S.W.O.T analysis, statistically one-dimensional frequency analysis. ( $f$-absolute frequencies, $w=f / n * 100$ - relative frequency in percent), questionnaire survey. Results: Based on this pilot study have been created practical recommendation for integration through golf.
\end{abstract}

Key words: Social, Sport, Adaptation, Inclusion, Disabilities

\section{INTRODUCTION}

Modern developed and civilized society is based on the principles of democracy, humanism and pluralism. In his social center stands the person - the person with individual rights, duties and responsibilities. People are born different, unique, with individual desires, opportunities, dreams and interests, but with equal rights in society. Equality and the absence of any discrimination is a fundamental principle in advanced civil societies and social systems.

In every society, there are people and groups who are marginalized for some reason - long-term unemployed, with different addictions (alcohol, gambling, illicit substances and stimulants, people with different types of disabilities or social problems, etc.), they exhibit characteristics that make them are different from generally accepted norms of behavior. We must not forget that they are part of society, they are among us, and we must accept them as equal persons, recognizing their right to be different. Of course, the power of this inclusion will be to a different extent, determined mainly by the individual characteristics of each of them, but let us not forget that the maturity of a society is determined by its attitude towards people with disability, irrelevant by their gender, race, social or economic status or ethnicity (Modified Rules of Golf for Players With Disabilities,2018). We claim to be a highly organized technological and civilized society that has the resources to care for the survival of people with disability. Unfortunately, this rarely happens. We need change and why should sports not be a catalyst for this metamorphosis? Sports can be the architect of our lives, it can build bridges where there are barriers or walls.

For hundreds of years, golf has inspired millions of people around the world (Damyanova, 2001). Considered to be a gentleman's sports, golf makes it possible to build many qualities in practitioners. All the rules of golf are about justice, there are no referees in the game, and it relies on the honest word of the players. In addition to developing a driving culture, players also learn a number of life-relevant 
qualities such as discipline, fair play, fairness (Amateur status, 2018). This sport is one of the most popular in the world, and it greatly supports personal development through the development of skills such as concentration, coordination, discipline, honesty, respect for the opponent, teamwork skills and proper behavior.

Golf has long become as a sport that not only brings pleasure and fun but is also a powerful tool and vehicle for social change. This sport is practiced by everyone - men and women, poor and rich, of different ethnicity or religion, of people of different sexual orientations. Practice shows that more and more people with disability find the sports in golf, which brings them confidence, self-affirmation, motivation and social contacts in our modern society (Modified Rules of Golf for Players with Disabilities, 2018). Its practice does not discriminate different social groups, it builds bridges between different groups and persons at risk of social exclusion. From the perspective of people with disabilities, this sport is an ideal tool for social integration (Damyanova, 2005). And here we have to ask ourselves - what are the best tools and models for integration? Can the practice of golf or adapted physical activity support and / or improve the process of social integration?

According to various professionals who work with people at risk of social exclusion, disadvantaged or at-risk youth, systematic and focused sports activities have a positive effect on their social adaptation. They have noticed that regular and focused physical activity brings educational benefits because of the values it promotes - respect, tolerance and self-control. Sports can lead to positive social change and can be used as a tool for prevention and education on topics such as socialization, integration, discrimination, racism and violence. There are thousands of evidences of how sports can create bridges where boundaries usually exist, giving participants a lesson in teamwork, empathy and empathy for their teammates and respect for their opponents and opponents. Sports teach us important life skills for goal setting, develop a strong sense of ethics, behavior and morality and provokes a positive development of diversity. (Damyanova, 2007).

The aim of this pilot study is to clarify the mechanisms and the interested individuals and legal entities from the successful implementation of programs for socialization, social adaptation and integration through golf for persons at risk of social exclusion. The objectives of the study

The subject of the research are the attitudes and desire for integration, lasting social adaptation and re-socialization through golf among the respondents.

\section{METHODS}

In order to be as accurate as much as possible in the results presented in this study, we have combined diverse data collection methods that could be synthesized into the following groups - structural content analysis, good practice analysis, S.W.O.T analysis, statistically one-dimensional frequency analysis. ( $\mathrm{f}$ - absolute frequencies, $\mathrm{w}=\mathrm{f} / \mathrm{n}{ }^{*} 100$ - relative frequency in percent), questionnaire survey.

\section{RESULTS}

According to a 2016 survey by the National Statistics Institute on Poverty and Social Inclusion, over $40 \%$ of our population is at risk or at risk of poverty or social exclusion, which equates to around 3 million people (NSI, 2018). The same survey shows that, statistically speaking, golf clubs in Bulgaria are at key places and can assist with appropriate programs with appropriate national funding for the processes and policies for integration, socialization and even economic prosperity in these areas. In the northeast region more than 450,000 people are at risk of social exclusion lives, and there are 3 exceptionally well-functioning golf clubs - Lighthouse Golf Resort, Black Sea Rama and Thracian Cliffs. In the southwestern region, the number of people at risk of poverty and social exclusion is even greater - over 740 thousand people. There are also 3 golf clubs in the area - Pirin Golf, Pravets Golf and St.Sofia GolfClub \& SPA, which have a large and modern base, staff of experienced professionals and the necessary skills to engage in initiatives and programs for integration, socialization and adaptation of endangered persons and groups of the population (Golf courses, 2018).

Based on the processed results, we conducted S.W.O.T - an analysis of the opportunities and prospects for golf development as a tool for integration and introduction of good practices for golf integration in Bulgaria (Table 1). 
Table 1.S.W.O.T analysis

\begin{tabular}{|c|c|}
\hline STRENGTHS & WEAKNESSES \\
\hline $\begin{array}{l}\text { In many places, the golf complexes have a SPA center - } \\
\text { a condition for the development of combined prevention, } \\
\text { rehabilitation and treatment through sports. } \\
\text { Prices of golf services in Bulgaria are lower in comparison } \\
\text { with other golf destinations in Europe. } \\
\text { Bulgaria's EU membership contributes to the development } \\
\text { of golf in Bulgaria, including as a tool for socialization and } \\
\text { adaptation. } \\
\text { Golf has a strong social function and generates high } \\
\text { income for charity. } \\
\text { Golf encourages the attraction of foreign investment in } \\
\text { the public and private sectors. Due to the more favorable } \\
\text { natural, climatic, economic and financial conditions, } \\
\text { Bulgaria is a potentially more attractive golf destination. } \\
\text { Many golf courses in our country are surrounded by } \\
\text { natural landscape. }\end{array}$ & $\begin{array}{l}\text { Bulgaria maintains a low standard of living and golf } \\
\text { is still an expensive sport, making it inaccessible to a } \\
\text { large part of the Bulgarian population. } \\
\text { There is insufficient advertising and promotion that } \\
\text { is a minus the development of the sport of golf in our } \\
\text { country. } \\
\text { There is still not enough trained and qualified } \\
\text { personnel in golf complexes, especially regarding the } \\
\text { use of sport as an integration tool. } \\
\text { The state does not invest in golf projects or the } \\
\text { financial support it provides is insufficient. } \\
\text { The capital investment needed to build a golf complex } \\
\text { is huge and the return is slow and time consuming. } \\
\text { High costs during the summer for irrigation and } \\
\text { maintenance of lawns in golf complexes. }\end{array}$ \\
\hline OPPORTUNITIES & THREATS \\
\hline $\begin{array}{l}\text { Hosting more golf tournaments with world renown at golf } \\
\text { courses in Bulgaria. } \\
\text { Promoting golf as a sport in Bulgaria among the local } \\
\text { population and golf players worldwide. } \\
\text { Promoting golf lessons among children. } \\
\text { Improvement of advertising and promotion of golf in } \\
\text { Bulgaria. } \\
\text { Establishment of a state plan and strategy for the } \\
\text { construction of golf courses in underdeveloped economic } \\
\text { areas and natural areas. }\end{array}$ & $\begin{array}{l}\text { The high cost of golf services. } \\
\text { A prerequisite for the emergence of some } \\
\text { environmental issues (noise and traffic congestion, } \\
\text { shocking visual landscapes, destroying homes and } \\
\text { breeding grounds and food sources for a wide range } \\
\text { of plants, animals and insects). } \\
\text { Low rate of operation of golf courses and complexes } \\
\text { in Bulgaria. } \\
\text { Bankruptcy risk and non - return on investments. }\end{array}$ \\
\hline
\end{tabular}

Conclusions from S.W.O.T analysis:

- There is a lack of significant national financial resources that support golf integration in Bulgaria;

- The lack of a legal framework for golf integration hinders the adaptation and socialization of significant groups of people;

- The lack of a sufficient number of qualified staff employed to deal with mental, physical or sensor disabilities in golf clubs demotivates significant social groups;

- Insufficient funding and public policy limits golf clubs in dealing with these social groups;

- One of the ways to promote Bulgaria as a tourist destination is through golf as a tool for social, prophylactic, sports, cultural and biomedical tourism;

- Integration through sports, and in particular through golf, would increase the social and economic activity of the population and in a huge number of cases would have a positive effect on entire regions of the country investments, increased employment levels, development of a tourist destination, increased corporate social responsibility and donation.

In order to collect the necessary empirical data, a special questionnaire was developed in Bulgarian, consisting of 13 closed-ended questions. A survey of attitudes to the needs of methodologies and programs that use golf as a tool for socialization and adaptation of people with disability was conducted among 95 people $(\mathrm{N}=95)$. These include 31 women and 64 men.

Different data has been revealed in the following parts of the current research such as:

- Respondents have a direct bearing on the need for processes and methods of integration and socialization of their close friends, relatives or acquaintances. Such connection is shown by nearly $3 / 4$ of the answers $(76.8 \%)$ - strong commitment of the persons who answered the question with a positive answer;

- Among the risks identified by the respondents to people with disability with the highest priority are social exclusion (21.7\%), depression (19.9\%) 
and less opportunity for these people to start a new job (19.2\%). All these factors, together with the risk of poverty (17.1\%), show the clear need for well-functioning and practically effective integration and social inclusion programs;

- Most of them respondents believe that golf can influence as a catalyst for social change (78.9\%) - evidence that big part of our society believes in the integration possibilities of this sport;

- Most respondents (88.4\%) did not participated or are unaware of programs that use golf as an integration tool, despite their strong involvement and interest in the topic;

- The respondents answered that they would participate in a program using golf as a tool for social integration $(82.8 \%)$.

\section{DISCUSSION}

The results obtained suggest that golf can successfully enhance integration processes in society, as well as improve the social inclusion of all social groups at risk. Golf has immense potential for combating youth unemployment, provoking and developing the various social knowledge, skills and competences that everyone needs, regardless of their social status, gender, race, or ethnicity.

At the same time, the survey identified numerous barriers faced by people with disabilities, refugees, migrants, children with special educational needs, the long-term unemployed or other groups at risk of being socially excluded if they wish to participate in sports or physical activity. These include cultural and linguistic barriers, practical and financial constraints, and a lack of appropriate sports programs.

On the basis of the research we have formulated the following conclusions:

- It is clear that there are good practice models that use golf as an integration tool and recommendations need to be developed to encourage increased participation of affected groups in sport and physical activity;

- Through golf, we can successfully increase the integration processes in society and improve the social inclusion of all social groups at risk;

- Golf has immense potential for combating youth unemployment, provoking and developing the various social knowledge, skills and competences that everyone needs, regardless of their social status, gender, race, or ethnicity;

- We must use the role that sport can play in strengthening communities and promoting inclusion;

- Promote tailored sports and leisure programs that can easily affect the physical and mental health of participants;

- To motivate physical activity and a healthy lifestyle through sports;

- A coordinated and integrated approach between state and non-governmental organizations (state and local authorities, non-governmental organizations and the sports sector / including sports federations and sports clubs) is needed in order to address such challenges to the integration and socialization of persons at risk of social exclusion;

- Participation in physical activity and sports has numerous health benefits, both physically (such as improving health and reducing the risk of chronic diseases) and psychologically (such as building the right social and personal qualities, countering stress and depression, increasing self-esteem, discipline and organizational capabilities);

- The study outlines the social benefits of sport, noting that increased participation in sport can help reduce crime and anti-social behavior and deviant behavior and build social cohesion.

- Golf is a common language that can be used as a tool useful and effective for integration into society, which can foster and along with education, bring values such as tolerance, freedom, justice, respect and etc.;

- Golf is useful for breaking stereotypes, facilitating the process of integration of immigrants and minorities in society, promoting mutual understanding and dialogue between cultures, it is a universal language and facilitates the process of social inclusion;

- Golf does not discriminate on any grounds, such as gender, race, color, ethnic or social background, genetic traits, language, religion or belief, disability, age or sexual orientation.

- After completing this study, we can make the following recommendations:

- Financing state programs that use the sport of golf for treatment, rehabilitation, rehabilitation and prevention at the Ministry of Defense, National Intelligence Service, National Security Service and Ministry of Interior;

- Local and national authorities to encourage interest in sports organizations and professionals in creating sustainable programs for integration 
through sport and in particular sport golf as a unique and powerful tool for socialization and the development of personal and social qualities;

- Provide greater opportunity for young people to exchange ideas and experiences on the topic and thus increase the added value of local communities in the processes of integration and combating multicultural differences;

- Increase knowledge and acquire new skills, knowledge and methods for sports and outdoor activities as tools for integration and education;

- Golf clubs, municipal, regional and national authorities and ministries to clarify the problems and challenges facing sport and golf in particular as a tool for integration and education in content and methodology, in the process of non-formal learning, intercultural differences and influencing the local community;

- Raising awareness of the personal, social and professional realization of participants in such integration programs;

- Improving the provision of information on poverty and social exclusion policies in terms of their causes, dimensions and manifestations;

- Study and exchange of good practices between EU Member States and stakeholders at national and local level to tackle poverty and social exclusion;

- Strengthening dialogue and stakeholder consultation on poverty and social exclusion;

- Introduce social impact assessment in all policy areas, incl. and conducting independent social impact assessments on a regular basis;

- Implementation of targeted program and project financing for the activities of state and nongovernmental sports organizations using sport golf as a tool for social change and socialization and working with citizens and individuals at risk of social exclusion, which would have a significant impact on enhancing the safety and well-being of local people community.

We need to focus on new methods, a new approach and new systems that will benefit our societies because we believe that in order to tackle issues like poverty, unemployment and social inequality, it is important to use the universal language of sport, a language that can unite society and is a great and powerful tool for integration. It is of the utmost importance for society to continue to work on the topic by promoting and guaranteeing greater impact on problems and solutions in this area, promoting good practices for integration and social inclusion. However, such methods should be reported at the state level and targeted, with specific national policies for obtaining a worthy place for sport as an integration tool that produces excellent results in many countries around the world. In a globalized world, it is only through joint action that we have the opportunity to meet the impending social, cultural, ethnic, racial, environmental, economic and security challenges. Let us, through the golf, transform negative emotions such as insecurity and a sense of powerlessness into new European ideas of democracy, integration, security and pluralism.

\section{REFERENCES}

Amateur status. (2018). Retrieve from USGA: https:// www.usga.org/rules-hub/amateur-status.html

Damyanova, R. (2001). Pravilata na Golfa, Sofia Press, Sofia

Damyanova, R. (2005). Naredbi na BGA/EGA, NSA Press, Sofia

Damyanova, R. (2007). Pravilnik po golf, NSA Press, Sofia

Golf courses. (2018). Retrieve from Golf.bg: http://golfbg.com/golf-courses/index/bg

Modified Rules of Golf for Players with Disabilities. (2018). Retrieve from USGA: https://www.usga.org/ rules/modified-rules-players-disabilities.html (accessed on Sept, 10th 2019)

NSI. (2018). Retrieve from NSI.bg: http://www.nsi.bg/ (accessed on Sept, 10th 2019)

Corresponding author: Ivaylo Zdravkov

National Sports Academy "Vassil Levski", Sofia, Bulgaria

E-mail: zdravkov.nsa@gmail.com 